\title{
Variations on the Pear Tree experiment: different variables, new results?
}

\begin{abstract}
Inspired by the Pear Stories Project, the Pear Tree Project has investigated how different cultures and languages describe the same film in order to apply its findings to audio description (AD). Participants from different countries were asked to "write down what they saw" in a controlled setting. This article proposes an alternative experiment, also based on the original Pear Stories Project, which aims to shed light on two issues: how different describer profiles (translation students with AD training/without AD training) and different instructions concerning the target audience profiles (blind/non-blind) could alter the final production. The results are analysed in this paper, taking into account the elements covered in the original Pear Stories Project as well as some additional elements proposed by the authors.
\end{abstract}

Keywords: audio description, audiovisual translation, perception, culture

\section{Introduction}

The Pear Tree film was created in the mid-1970s for an experiment which aimed to examine the reception of a visual story in different languages and cultures (Chafe 1980), and has been used in subsequent studies in various countries (Tannen 1980, for instance). Its application to the field of audio description (AD) was proposed by Orero, who in a 2007 experiment asked 20 students with no prior knowledge of AD to "write what they remembered as if they were explaining to a friend the film they've just seen" (Orero 2008: 184). The idea was developed further in the Pear Tree Project (PTP), as part of the European Project DTV4ALL (see Mazur and Chmiel 2011, in this volume): the aim was to study how the same film was described in various languages in order to apply its findings to AD. The proposed PTP departed from Chafe's original Pear Stories Project (PSP): although the same clip was used, some of the parameters of the experiment were changed. For example, within the PSP framework participants recounted orally what they saw after some time, whereas in the PTP participants were asked to "write down what they saw".

The research presented in this article has also been inspired by the original PSP and proposes an alternative experiment which, although not directly comparable to the PTP due to the changes in the experimental design, will hopefully yield some interesting results per se and will open the door to future research in which further variables are taken into account. In fact, it is our belief that slightly different settings, different instructions and different participants' profiles could significantly alter the final results. In other words, modifying variables such as the channel of communication (oral/written), the number of viewings (one viewing/no restriction on viewings), the target audience profile (sighted/blind audience) or the describer's profile (previous AD training/no AD training), amongst others, could provide new data directly relevant to how people describe a visual input in various languages and cultures under different conditions.

Due to the impossibility of analysing all variables, the final aim of this particular piece of research is to carry out a pilot study to assess how the final production might be influenced in a given language (Catalan, in this case) as a result of altering two variables: 
(1) Describer profile: translation students trained in AD and translation students with no AD training;

(2) Addressee profile: blind vs. general audience.

This article presents, in the first instance, methodological issues concerning the experiment. Next, it summarises the results taking into account the aspects analysed in the original PSP. The variables "describer profile" and "addressee profile" are considered in the analysis in order to address possible differences in the result set. After this analysis, the article evaluates additional parameters in order to find out if having previous $\mathrm{AD}$ training and if providing to the subjects an instruction that the target audience is blind alters the way a film is described. Two key issues are analysed: what is described - focusing on the setting, the main characters and the actions - and how - focusing on the use of adjectives. The article ends with some general conclusions drawn from all of the results and presents some future research possibilities.

\section{The experiment: methodological issues}

The experiments for the current investigation were carried out at the Universitat Autònoma de Barcelona (UAB) between 13th May 2010 and 30 April 2011. The aim was to undertake a pilot study, so a limited yet significant number of subjects were chosen (ten per group). Two variables were altered and the final result was four test groups (Table 1), with a total number of 40 participants.

\begin{tabular}{|l|l|l|}
\hline & Describer profile & Addressee profile \\
\hline Group 1 (10 subjects) & AD training & Blind \\
\hline Group 2 (10 subjects) & AD training & General \\
\hline Group 3 (10 subjects) & No AD training & Blind \\
\hline Group 4 (10 subjects) & No AD training & General \\
\hline
\end{tabular}

Table 1. The groups

As for the describers' profiles, groups 1 and 2 included translation students who had been trained in $\mathrm{AD}$ in the MA in Audiovisual Translation offered by the Universitat Autònoma de Barcelona (4 ECTS, 20h of lecturing plus autonomous work), while groups 3 and 4 were made up of translation students with no AD training. They were all female between 21 and 36 years old. As for the addressees' profiles, groups 1 and 3 were asked to address a blind audience, whereas groups 2 and 4 were asked to address a general audience.

After randomly selecting the participants, following a procedure approved by the ethical committee at $\mathrm{UAB}$, subjects were called individually for the experiment at the university premises. They were informed of the experiment and were asked for their free consent for the use of their data. After watching the six-minute clip on a computer screen, they were given the instructions below:

- Groups 1 and 3. Write down what you have seen as if you were addressing a blind friend.

- Groups 2 and 4. Write down what you have seen as if you were addressing a friend. 
The desired output was a written text and the language chosen was Catalan. They were asked to write the text on a computer and allowed an unrestricted number of viewings, so as to avoid results impacted due to memory issues. Time was limited to an hour but many of the subjects only devoted 40 minutes to the experiment. The result was a corpus of written descriptions with 27,221 words (8,092 for group 1, 6,374 for group 2 , 5,878 for group 3 and 6,877 for group 4 ).

\section{Results of the experiment: the PSP parameters}

The corpus of texts was analysed initially using the same parameters as in the original PSP: maintenance of film perspective, description of actions, interpretation of events, interpretative naming, interpretative omission, attribution of causality, stylistic variation, and interpretation of other events. For further information on each of these items and its relevance for AD, see Chmiel and Mazur (2011, in this volume). The results are discussed in the following sub-sections, taking into account the two altered variables (target audience/previous training) and are complemented with an additional analysis in section 4 .

\subsection{Maintenance of film perspective}

Regarding the maintenance of film perspective, this element was firstly assessed by evaluating the percentage of texts with occurrences of the word "movie" and its synonyms (Table 2$)$.

\begin{tabular}{|l|l|l|l|l|l|}
\hline Number of occurrences & $\mathbf{0}$ & $\mathbf{1}$ & $\mathbf{2}$ & $\mathbf{3}$ & $\mathbf{4}$ \\
\hline G1 (blind/AD training) & $60 \%$ & $20 \%$ & $10 \%$ & $10 \%$ & $0 \%$ \\
\hline G2 (general/AD training) & $30 \%$ & $50 \%$ & $10 \%$ & $10 \%$ & $0 \%$ \\
\hline G3 (blind/no AD training) & $40 \%$ & $40 \%$ & $20 \%$ & $0 \%$ & $0 \%$ \\
\hline G4 (general/no AD training) & $50 \%$ & $10 \%$ & $0 \%$ & $30 \%$ & $10 \%$ \\
\hline
\end{tabular}

Table 2. Number of occurrences of the noun "movie" and synonyms

The highest percentages reflect no mention of the term or its synonyms $(60 \%$ in group $1 ; 50 \%$ in group 4 , and $40 \%$ in group 3 ) and just one mention (50\% in group 2 and $40 \%$ in group 3). The synonyms used are the Catalan version of "short-movie", "video", and "clip". Although no clear pattern arises when taking into account the target audience and the previous training combinations, the highest percentage of no mentions of the word "movie" and its synonyms is found in students with AD training addressing a blind audience. Current AD guidelines discourage the use of technical terms, as indicated in a comparative study published by the RNIB (2010) which analyses the Spanish Standard UNE 153020, the German AD guidelines, the French Audio Description Charter, Audio Description International's proposed guidelines, a Greek working document as well as the OfCom Draft Guidelines. Hence, although additional information would be needed to make a clear statement on this issue, it would not be farfetched to suggest that the criteria explained in class to the trained AD subjects in this regard probably influenced the output of some members of group 1. 
The number of allusions to the film as film or film-viewer perspective was also considered (Table 3).

\begin{tabular}{|l|l|l|l|l|}
\hline Number of allusions & $\mathbf{0}$ & $\mathbf{1 - 4}$ & $\mathbf{5 - 8}$ & $\mathbf{8 - 1 2}$ \\
\hline G1 (blind/AD training) & $40 \%$ & $20 \%$ & $20 \%$ & $20 \%$ \\
\hline G2 (general/AD training) & $10 \%$ & $70 \%$ & $10 \%$ & $10 \%$ \\
\hline G3 (blind/no AD training) & $10 \%$ & $60 \%$ & $20 \%$ & $10 \%$ \\
\hline G4 (general/no AD training) & $10 \%$ & $70 \%$ & $10 \%$ & $0 \%$ \\
\hline
\end{tabular}

Table 3. Number of allusions to the film as film or film-viewer perspective

Most reports (60-70\% of groups 2, 3 and 4) make between one and four allusions to the video as a film, whilst the highest percentage in group $1(40 \%)$ corresponds to "no filmic allusions", in line with the results of the previous aspect that has been analysed.

Some of the allusions found in the current experiment are the following: "curt" [short film], "primera escena" [first scene], "un personatge"[a character], "davant la càmera" [in front of the camera], "la pel·lícula" [the film], "l'espectador" [the spectator] (group 1), "l'escena" [scene], "l'acció té lloc" [action takes place], "una història" [a story], "els protagonistes" [the main characters] (group 2), "el vídeo [video], "el curt" [short film]", "l'acció" [action], "el protagonista" [main character], "la història" [the story], "en primer pla" [in close-up] (group 3), and "escena" [scene], "història" [story], "personatges" [characters], "canvi d'escena" [change of scene] (group 4), among others.

It is also interesting to note the use of expressions referring to sight or hearing, regardless of the group and despite the recommendations to avoid this type of expression when addressing a blind audience in an AD (Remael 2005, Audetel 2000). In group 1 (blind/AD training) the expressions found are "se senten" [are heard] (2 occurrences), "la pel·lícula ens mostra" [the film shows us] (1 occurrence), "veiem" [we see] (2 occurrences) or "es veu" [one sees] (1 occurrence). In group 2 (general/AD training), the formulations are "sentim" [we hear], (2 occurrences), "(els) veiem" [we see (them)] (6 occurrences) and "ens adonem" [we realise] (1 occurrence). Group 3 (blind/no AD training) presents the following: "veiem" [we see] (3 occurrences), "es veu" [one sees] (2 occurrences), "no se'l torna a veure" [he is not seen again] (1 occurrence). Finally, in group 4 (general/no AD training), two allusions are found: "podem observar" [we can observe] (1 occurrence) and "es torna a veure" [is seen again] (1 occurrence).

It is also worth noting that the lack of dialogue in the film is mentioned by $20 \%$ of the participants in groups 1 and 3,30\% in group 2, and 20\% in group 4. No subjects refer to the limited role of any of the characters.

\subsection{Description of actions}

Concerning the description of actions, the emphasis has been put on the verb tenses used by the participants. The results show that most subjects, with percentages varying between $100 \%$ (group 2) and 60\% (groups 1 and 3), only use the present tense, whilst practically all the rest mix tenses (Table 4), the exception being $10 \%$ of group 3 that use only the past. It seems, therefore, that the highest levels of consistency in the use of the 
present tense are found in subjects addressing a general audience (groups 2 and 4) regardless of their background but the authors can offer no explanation for this trend.

\begin{tabular}{|l|l|l|l|l|}
\hline Number of allusions & Present only & Past only & Mixed & Past>Present \\
\hline G1 (blind/AD training) & $60 \%$ & $0 \%$ & $40 \%$ & $0 \%$ \\
\hline G2 (general/AD training) & $100 \%$ & $0 \%$ & $0 \%$ & $0 \%$ \\
\hline G3 (blind/no AD training) & $60 \%$ & $10 \%$ & $30 \%$ & $0 \%$ \\
\hline G4 (general/no AD training) & $90 \%$ & $0 \%$ & $10 \%$ & $0 \%$ \\
\hline
\end{tabular}

Table 4. Verb tenses used in texts

\subsection{Interpretation of events}

Our interest also lies in the event where the boy gives pears to the other three boys. This is mentioned by all but approaches to its description vary significantly: the description is very basic in $20 \%$ of the subjects in group 1 and 2 and in $10 \%$ of the subjects in group 3 . None of the subjects make a moral judgment but a remarkable percentage refers to this being a gesture of thanks ( $80 \%$ in groups $1,2,3$, and $90 \%$ in group 4$)$.

\subsection{Interpretative naming}

As for the words used to refer to the pear-picker, Table 5 summarises the main results. As done by Tannen (1980: 71) and also by Chmiel and Mazur in this volume, it classifies words as non-interpretative (for example, "man", "guy"), particular (for example, "pear-picker") or interpretative (for example, "farmer"). The table shows the percentage of subjects that use a specific name for the pear-picker and, of these subjects, the percentage that use a particular term the first time the pear-picker is mentioned. 


\begin{tabular}{|c|c|c|c|}
\hline G1 (blind/AD training) & & $\begin{array}{l}\text { Number of } \\
\text { subjects }\end{array}$ & $\begin{array}{l}\text { Of these subjects, } \\
\text { percentage in } \\
\text { which this term is } \\
\text { used at the first } \\
\text { mention of the } \\
\text { pear-picker }\end{array}$ \\
\hline \multirow[t]{2}{*}{ Non-interpretive } & "home" $[\mathrm{man}]$ & $100 \%$ & $40 \%$ \\
\hline & "senyor" [formal word for man] & $10 \%$ & $0 \%$ \\
\hline Particular & $\begin{array}{l}\text { "recol·lector de fruita" and } \\
\text { variants [fruit picker] }\end{array}$ & $30 \%$ & $10 \%$ \\
\hline \multirow[t]{3}{*}{ Interpretive } & $\begin{array}{l}\text { "home que cull peres" and variants } \\
\text { [man that picks pears and similar } \\
\text { structures] }\end{array}$ & $60 \%$ & $20 \%$ \\
\hline & "pagès" [peasant] & $30 \%$ & $30 \%$ \\
\hline & "camperol" [farm worker] & $10 \%$ & $10 \%$ \\
\hline \multicolumn{4}{|l|}{ G2 (general/AD training) } \\
\hline \multirow[t]{2}{*}{ Non-interpretive } & "home" [man $]$ & $50 \%$ & $30 \%$ \\
\hline & "senyor" [formal word for man] & $10 \%$ & $10 \%$ \\
\hline \multirow[t]{3}{*}{ Interpretive } & "camperol" [farm worker] & $50 \%$ & $10 \%$ \\
\hline & “pagès" [peasant] & $70 \%$ & $30 \%$ \\
\hline & $\begin{array}{l}\text { "home que cull peres" and variants } \\
\text { [man that picks pears and similar } \\
\text { structures] }\end{array}$ & $30 \%$ & $20 \%$ \\
\hline G3 (blind/no AD training) & & $\begin{array}{l}\text { Number of } \\
\text { subjects }\end{array}$ & \\
\hline \multirow[t]{2}{*}{ Non-interpretive } & "home" [man $]$ & $90 \%$ & $40 \%$ \\
\hline & "senyor" [formal word for man] & $20 \%$ & $0 \%$ \\
\hline \multirow[t]{2}{*}{ Interpretive } & $\begin{array}{l}\text { "home que cull peres" and variants } \\
\text { [man that picks pears and similar } \\
\text { structures] }\end{array}$ & $70 \%$ & $30 \%$ \\
\hline & "camperol" [farm worker] & $30 \%$ & $20 \%$ \\
\hline $\begin{array}{l}\text { G4 (general /no } A D \\
\text { training) }\end{array}$ & & $\begin{array}{l}\text { Number of } \\
\text { subjects }\end{array}$ & \\
\hline \multirow[t]{2}{*}{ Non-interpretive } & "home" $[\mathrm{man}]$ & $80 \%$ & $60 \%$ \\
\hline & "senyor" [formal word for man] & $10 \%$ & $0 \%$ \\
\hline \multirow[t]{4}{*}{ Interpretive } & “camperol” [farm worker] & $10 \%$ & $10 \%$ \\
\hline & $\begin{array}{l}\text { "home que cull peres" and variants } \\
\text { [man that picks pears and similar } \\
\text { structures] }\end{array}$ & $80 \%$ & $20 \%$ \\
\hline & “pagès" [peasant] & $20 \%$ & $10 \%$ \\
\hline & $\begin{array}{l}\text { "home de les peres" [ man of the } \\
\text { pears] }\end{array}$ & $10 \%$ & $0 \%$ \\
\hline
\end{tabular}


Table 5. Naming the "pear-picker"

The form which is more widely used by most subjects is the non-interpretative form "home" [man], although interpretative forms such as "home que cull peres" [ man that picks pears] and similar structures are present in notable percentages. The most interesting issue, in our opinion, is that the only particular form is found in those with AD training addressing a blind audience: "recol-lector de fruita" [pear-picker]. As for the rest, no significant differences are found between the groups.

\subsection{Interpretative omission}

Another aspect worth addressing is interpretative omission (Table 6), which is analysed by counting which of the objects (girl, rock, and hat) are mentioned in relation to the event where the boy falls off the bike.

\begin{tabular}{|l|l|l|l|l|}
\hline Texts Mentioning... & G1 & G2 & G3 & G4 \\
\hline Fall but none of $\{$ Girl, Rock, Hat $\}$ & $0 \%$ & $10 \%$ & $0 \%$ & $0 \%$ \\
\hline Girl only & $0 \%$ & $10 \%$ & $10 \%$ & $0 \%$ \\
\hline Rock only & $0 \%$ & $0 \%$ & $10 \%$ & $0 \%$ \\
\hline Hat only & $0 \%$ & $0 \%$ & $0 \%$ & $0 \%$ \\
\hline Girl and hat & $30 \%$ & $0 \%$ & $10 \%$ & $10 \%$ \\
\hline Hat and rock & $0 \%$ & $0 \%$ & $0 \%$ & $0 \%$ \\
\hline Girl and rock & $10 \%$ & $10 \%$ & $10 \%$ & $20 \%$ \\
\hline Girl, rock, hat & $60 \%$ & $70 \%$ & $60 \%$ & $70 \%$ \\
\hline Table 6 .
\end{tabular}

Table 6. Objects mentioned in bike fall scene

In all groups the percentages of subjects that mention the three objects are between $60 \%$ and $70 \%$. The rest of the results do not present a clear pattern that can be attributed to the variables that have been modified.

\subsection{Attribution of causality}

When explaining the cause of the fall, it is difficult to establish a clear-cut distinction based on the proposed set of causes in the original project. However, the results of the main cause indicated by the subjects in their texts are the ones gathered in Table 7 .

\begin{tabular}{|l|l|l|l|l|}
\hline Cause... & G1 & G2 & G3 & G4 \\
\hline Turning and hitting rock & $50 \%$ & $90 \%$ & $60 \%$ & $80 \%$ \\
\hline Tripping on rock & $20 \%$ & $0 \%$ & $20 \%$ & $10 \%$ \\
\hline Looking at girl & $20 \%$ & $10 \%$ & $0 \%$ & $0 \%$ \\
\hline Meeting with girl & $0 \%$ & $0 \%$ & $10 \%$ & $10 \%$ \\
\hline Collision with girl & $0 \%$ & $0 \%$ & $10 \%$ & $0 \%$ \\
\hline
\end{tabular}




\begin{tabular}{|l|l|l|l|l|}
\hline Cause... & G1 & G2 & G3 & G4 \\
\hline Rushing (and maybe also girl) & $0 \%$ & $0 \%$ & $0 \%$ & $0 \%$ \\
\hline Tipping hat & $10 \%$ & $0 \%$ & $0 \%$ & $0 \%$ \\
\hline
\end{tabular}

Table 7. Explanations of cause of fall

Most subjects indicate the turning and hitting of a rock as the main cause of the fall, with percentages as high as $80 \%$ (group 4) and 90\% (group 2). The group with the lowest percentage in this case is group 1, where $20 \%$ of the participants attributed the fall to "tripping on rock", $20 \%$ to the act of "looking at the girl" and $10 \%$ to the act of "tipping of the hat".

\subsection{Stylistic variation}

To refer to the threesome most subjects use the term "nois" [boys] although other variants are used, as shown in Table 8, which indicates the terms used, the number of times each term is used in total, the percentage of texts using this term and the percentage of texts in which this term is used for the first mention of the threesome. 


\begin{tabular}{|c|c|c|c|}
\hline $\begin{array}{l}\text { G1 (blind } / A D \\
\text { training) }\end{array}$ & $\begin{array}{l}\text { Number of mentions } \\
\text { of this term in total }\end{array}$ & $\begin{array}{l}\text { Percentage of texts using } \\
\text { this term }\end{array}$ & $\begin{array}{l}\text { Percentage of texts in } \\
\text { which this term is used for } \\
\text { the first mention of the } \\
\text { threesome }\end{array}$ \\
\hline "nois" [boys] & 11 & $40 \%$ & $30 \%$ \\
\hline "nens" [children $]$ & 25 & $70 \%$ & $60 \%$ \\
\hline $\begin{array}{l}\text { "nins" [ dialectal } \\
\text { variant of children] }\end{array}$ & 3 & $10 \%$ & $10 \%$ \\
\hline $\begin{array}{l}\text { "grup de nois" } \\
\text { [group of boys] }\end{array}$ & 2 & $10 \%$ & $0 \%$ \\
\hline $\begin{array}{l}\text { "companys" [friends, } \\
\text { almost colleagues }]\end{array}$ & 3 & $30 \%$ & $0 \%$ \\
\hline "amics" [friends] & 2 & $20 \%$ & $0 \%$ \\
\hline "noiets" [little boys] & 1 & $10 \%$ & $0 \%$ \\
\hline \multicolumn{4}{|l|}{$\begin{array}{l}\text { G2 (general/AD } \\
\text { training) }\end{array}$} \\
\hline "nens" [children $]$ & 28 & $100 \%$ & $90 \%$ \\
\hline "amics" [friends] & 4 & $40 \%$ & $0 \%$ \\
\hline $\begin{array}{l}\text { "la colla de nens" } \\
\text { [the group of } \\
\text { children] }\end{array}$ & 4 & $30 \%$ & $10 \%$ \\
\hline "companys" [mates $]$ & 1 & $10 \%$ & $0 \%$ \\
\hline \multicolumn{4}{|l|}{$\begin{array}{l}\text { G3 (blind/no } A D \\
\text { training) }\end{array}$} \\
\hline “nens" [young boys] & 25 & $60 \%$ & $50 \%$ \\
\hline "nois" [boys] & 12 & $40 \%$ & $40 \%$ \\
\hline "amics" [friends] & 4 & $40 \%$ & $10 \%$ \\
\hline \multicolumn{4}{|l|}{$\begin{array}{l}\text { G4 (general /no } A D \\
\text { training) }\end{array}$} \\
\hline “nens" [young boys] & 18 & $80 \%$ & $70 \%$ \\
\hline "nois" [boys] & 13 & $30 \%$ & $30 \%$ \\
\hline "germans" [brothers] & 1 & $10 \%$ & $0 \%$ \\
\hline "companys" [mates] & 1 & $10 \%$ & $0 \%$ \\
\hline "amics" [friends] & 2 & $20 \%$ & $0 \%$ \\
\hline
\end{tabular}

Table 8. Stylistic variation 
All texts, regardless of the training background and the intended target audience, use either "nois" [boys], "nens"/"nins" [children] or "la colla de nens" [the group of children] when first mentioning the threesome. Other variants are derived from these previous terms, such as "grup de nois" [group of boys] or "noiets" [little boys]. Evaluative descriptions related to the notion of friendship ("companys" [mates], "amics" [friends]) are also found in all groups. One informant in group 4, without AD training and addressing a general audience, describes the group as possibly brothers, "nens que deuen ser germans" [children which are probably brothers].

Another issue which was analysed in the original project was the description of the man with a goat who appears at the beginning of the film. Although it has no relevance to the plot, in the current experiment it is mentioned by most subjects: $90 \%$ in groups 1 and 4,100\% in group 3 and $80 \%$ in group 2. Some participants are not sure or simply wrong about the nature of the animal and provide an inaccurate description, despite the fact that they were given the opportunity to watch the film as many times as they wanted: "un animal (una cabra?)" [an animal (a goat?)] and "un burro" [a donkey] in group 1, "una ovella" [ a sheep] and "un cabrit" [a kid] in group 2, "un vedell" [a calf] in group 3 and "un animal, una mena de bambi" [an animal, something like a Bambi] are the expressions used.

Finally, a toy which has no name in most languages appears in the film. This fact is irrelevant for the development of the film but it is worth measuring the percentage of subjects that describe this element - percentages are included in the left hand (\% of partipants) column - and the expressions used to refer to it are transferred literally into the right hand column (Words used to describe the toy) in Table 9. This table illustrates whether participants prefer to omit the description of objects with no specific name or whether they adopt one of a range of lexical strategies to convey its main features to the addressee.

\begin{tabular}{|l|l|}
\hline $\begin{array}{l}\text { \% of } \\
\text { participants }\end{array}$ & Words used to describe the toy \\
\hline G1 (blind/AD training) \\
\hline $60 \%$ & $\begin{array}{l}\text { "una raqueta i una pilota lligada amb una corda a la raqueta" [a racket and a ball } \\
\text { tied with a rope to the racket] }\end{array}$ \\
\hline & $\begin{array}{l}\text { "una pala amb una piloteta lligada amb una goma" [a bat with a small ball tied to } \\
\text { an elastic band ] }\end{array}$ \\
\hline $\begin{array}{l}\text { "a una pilota que va lligada a la raqueta per un cordell" [a small ball tied to the } \\
\text { racket with a string] }\end{array}$ \\
\hline $\begin{array}{l}\text { "una pala que té una bola lligada amb una goma" [a bat with a ball tied with an } \\
\text { elastic band] }\end{array}$ \\
\hline $\begin{array}{l}\text { "una pala de fusta d'aquelles que tenen una piloteta amb una goma per fer-la } \\
\text { rebotar" [a wooden bat with a small ball and an elastic band to make it bounce] }\end{array}$ \\
\hline $\begin{array}{l}\text { "una pala de ping-pong que porta una pilota lligada amb un cordill" [a tennis } \\
\text { table ball with a ball tied with a string] }\end{array}$ \\
\hline G2 (general/AD training) \\
\hline "una pala" [a bat] (two occurrences) \\
$\begin{array}{l}\text { "una raqueta de la mida de les de tenis de taula, que porta un cordill enganxat al } \\
\text { centre de la raqueta i d'aquest cordill penja una pilota" [a table tennis-sized bat } \\
\text { with a string attached to the center of the racket, and from this string a ball } \\
\text { hangs] }\end{array}$ \\
\hline "una raqueta que duu una bola lligada" [a racket with a tied ball] \\
\hline $\begin{array}{l}\text { "una pala amb una pilota enganxada a aquesta a través d'una corda elàstica" [a } \\
\text { bat with a ball tied to it by means of an elastic rope] }\end{array}$ \\
\hline
\end{tabular}




\begin{tabular}{|l|l|}
\hline G3 (blind/no AD training) \\
\hline $40 \%$ & $\begin{array}{l}\text { "una pilota amb una pala (una pilota de ping-pong que està enganxada amb una } \\
\text { goma a la pala)" [a ball with a bat (a tennis table ball attached with an elastic } \\
\text { band to the bat)] }\end{array}$ \\
\hline & "una pala i una pilota" [a bat and a ball] \\
& $\begin{array}{l}\text { "una d'aqueles pales de pim pom que tenen una piloteta enganxada amb un } \\
\text { cordill" [one of those tennis table bats with a small ball tied with a string] }\end{array}$ \\
\hline & $\begin{array}{l}\text { "una pala de ping-pong que hi té una corda lligada amb una pilota petita que en } \\
\text { penja" [a tennis table bat with a rope tied to it and a small ball hanging from it] }\end{array}$ \\
\hline G4 (general//no AD training) \\
\hline $70 \%$ & $\begin{array}{l}\text { "una raqueta amb una pilota lligada amb un cordill" [a bat with a ball tied with a } \\
\text { string] }\end{array}$ \\
\hline & $\begin{array}{l}\text { "una pala d'aquelles que tenen una piloteta enganxada amb un cordill" [one of } \\
\text { those bats which has a small ball tied with a string] }\end{array}$ \\
\hline $\begin{array}{l}\text { "una mena de raqueta de tenis platja i una piloteta enganxada a la raqueta amb } \\
\text { una corda" [a sort of beach tennis racket and a small ball tied to the racket with a } \\
\text { rope] }\end{array}$ \\
\hline $\begin{array}{l}\text { "una pilota a una raqueta de pim pom (la raqueta i la pilota estan enganxades amb } \\
\text { un fil" [a ball to a tennis table bat (the bat and the ball are tied with a thread] }\end{array}$ \\
\hline "una pala de ping-pong" [a tennis table bat] \\
\hline & "una espècie de pala de ping-pong" [a sort of tennis table bat] \\
\hline "una raqueta petita amb una pilota" [a small racket with a ball]
\end{tabular}

Table 9. Reference to the toy

Directly referencing the toy could have been avoided as it is not central to the plot. However, while there is no specific name available in Catalan, the toy is described in most cases, ranging from $40 \%$ of participants in group 3 to $70 \%$ of group 4 . No clear patterns emerge from the results when analysed against the subject's profile and instructions. In other words, despite previous training in $\mathrm{AD}$, the degree of detail used in the description of the object is similar and, as one could expect, the various expressions selected rely on certain similar pivotal elements such as "pala" [bat] or "raqueta" [racket], "pilota" [ball] or "piloteta" [small ball], and "elastic" [elastic band], "corda" [rope] or "cordill" [string].

\subsection{Interpretation of other events}

This section aims to investigate whether the respondents describe events in a neutral way or if they interpret them subjectively. This is especially relevant because AD is supposed to be neutral and not include personal interpretations (Seibel \& Jiménez, forthcoming; Vercauteren 2007; Marzà 2010), although this is quite a thorny issue and is currently subject of much debate. In fact, further studies on how film narrative is interpreted (Remael \& Vercauteren 2007: 77-78) and how it can be better received by the target audience are still needed (Braun 2008: 11). Indeed such studies could be beneficial in shedding light on a topic where currently there is limited consensus. In order to facilitate the interpretation of other events, we will focus on the event where the boy takes the basket with the pears and the event where the pear-picker discovers that the basket has disappeared and his reaction to that fact. These two events have been chosen because they are analysed in the Pear Tree Project and can clearly show us if participants prefer to remain neutral in their descriptions or if they lend an interpretation to the facts. 
With regard to the first event, the following data have been obtained: no subjects fail to mention this event, and a low percentage (30\% of participants in groups 1 and 2 ; $20 \%$ in group 3 , and $10 \%$ in group 4 ) give a basic neutral description. In fact, most descriptions refer to this event as stealing, either directly or indirectly $(70 \%$ of participants in groups 1 and $2 ; 80 \%$ in group 3, and 90\% in group 4), although none include a moral judgement. This approach is similar to the one found in 3.3. (interpretation of events), when referring to the act of giving pears as a gesture of thanks.

In relation to the second event (Table 10), the following data have been extracted: the percentage of participants that do not refer to this event at all; the percentage that give a basic neutral description; the percentage that provide a description of the farmer's reaction or emotions; the percentage that interpret the reaction of the picker, and finally the percentage of subjects providing a description of both emotions and reaction of the picker.

\begin{tabular}{|l|l|l|l|l|}
\hline & $\boldsymbol{G 1}$ & $\boldsymbol{G} 2$ & $\boldsymbol{G 3}$ & $\boldsymbol{G 4}$ \\
\hline No reference & $0 \%$ & $0 \%$ & $0 \%$ & $0 \%$ \\
\hline Basic description & $40 \%$ & $30 \%$ & $20 \%$ & $30 \%$ \\
\hline Description of reaction or emotions & $40 \%$ & $60 \%$ & $70 \%$ & $50 \%$ \\
\hline Interpreting the reaction & $10 \%$ & $0 \%$ & $0 \%$ & $10 \%$ \\
\hline $\begin{array}{l}\text { Description of reaction and } \\
\text { emotion }\end{array}$ & $10 \%$ & $10 \%$ & $10 \%$ & $10 \%$ \\
\hline
\end{tabular}

Table 10. Reaction of the pear-picker

None of the subjects ignore this event and the most common approach is to provide a description of either the farmer's reaction or emotions, with variable percentages between $40 \%$ (group 1) and 70\% (group 3). Most descriptions use words in the semantic field of "sorpresa" [surprise], although other expressions are to be found: closer semantically-related variants such "estranyesa" [astonishment], "atònit" [amazed] or "desconcert" [puzzlement], and different emotions such as "sospitosament" [suspiciously], "ràbia" [anger] or "pensatiu" [thoughtful].

\subsection{Preliminary conclusions}

All in all, the results described above have not shown notable differences between the groups, either by taking into account the subjects' profile (AD training/no AD training) or indeed the specific instruction concerning the target audience (blind/general audience). This is in line with the PTP's results, which were also partially inconclusive: although 10 out of the 12 aspects analysed in the PTP yielded statistically significant differences between the languages, "the ten remaining aspects are too huge to allow justified generalisations and, additionally, some opposing tendencies, or trends maybe observed" (Chmiel and Mazur, this volume). As summarised in Chmiel and Mazur's article, some methodological issues may explain the PTP results:

"the researchers did not control for one confounding variable, i.e. the participants' AD experience and they were not asked about their previous exposure to AD. [...] Secondly, the participants were not instructed to provide a description to a blind person, 
but just to a friend and no reference was made throughout the experiment to the application of the results to AD".

These two variables have been directly addressed in this article but the results, again, show no clear trends. Our hypothesis was that students with AD training addressing a blind audience would show statistically significant differences in various aspects but this is simply not the case. Regarding the maintenance of film perspective, one would expect students trained in AD addressing a blind audience to omit technical terms and allusions to films. Indeed this trend is more accentuated in this group but, paradoxically, references to the fact that the narrator is "seeing" or "hearing" something are scattered equally across all groups and references to the lack of dialogue in the descriptions which would be obvious to a blind person - also have similar results across the groups.

Regarding the use of verbal tenses, UK Ofcom guidelines suggest using the present tense, the continuous present or the present participle because it is a real-time commentary. The results of our pilot study, however, show no significant differences attributable to background training in $\mathrm{AD}$ and, in fact, the group of $\mathrm{AD}$ students addressing a blind audience even shows a lower percentage in the use of the present tense compared to the groups addressing a general audience.

Interpreting events in a subjective manner has generally been discouraged within AD based on the standard guidelines. That said, the discussion between objective and subjective approaches to the description are still commonplace in the academic arena, as indicated previously. However, the two items analysed to investigate this issue - the act of giving pears as a gesture of thanks in 3.3., and also the act of stealing the basket in 3.8 - do not show significant differences between the groups, and explicitation is preferred rather than neutral description. Finally, interpretative naming and interpretative omission also show similar percentages in all groups, and no clear pattern can be found in the attribution of causality or indeed in the analysis of stylistic variation when referring to the threesome.

In fact, the similarity of the results obtained in most items analysed allows us to venture three feasible explanations: first of all, the items analysed were probably conceived to identify how stories are told in various languages and cultures, hence it might well be that story telling in a particular language - in this case, Catalan - is a more relevant factor and therefore immune to the altered variables, i.e. target audience or/and previous training. As put forward by Chafe (1980: xvi) regarding the PSP, "[t]he narratives, then, furnish evidence of the hypothesis that ways of telling about events are culturally determined and conventionalized". Secondly, the fact that no specific mention of $\mathrm{AD}$ was made throughout the experiment might have influenced the result, in other words, it might be that students trained in $\mathrm{AD}$ were not aware that they would have to put into practice what they have learnt in class. Finally, it is also possible that the limited number of participants biased the results and a bigger sample is needed to reach more conclusive results.

However, despite the conclusions above, we intuitively resisted the idea that altering the subjects' profile and the target audience does not make any difference, and this is why we decided to embark on a further complementary analysis in order to assess the impact of previous AD training on a set of additional items.

\section{Further analysis: previous training in AD, different results?}


An analysis was devised to approach the subjects' texts from a complementary perspective and find out if they presented further differences not detected in the previous research. As two variables had been altered, various possibilities for analysis arose, but we decided to focus on one aspect: the differences between the texts produced by students with $\mathrm{AD}$ training and by students without $\mathrm{AD}$ training, addressed in both instances to a blind audience (groups 1 and 3). Our specific aim was to investigate whether descriptions differed in terms of form focussing on issues specifically debated in the field of $\mathrm{AD}$.

In order to establish a set of parameters of analysis which would be relevant to AD, Marzà's (2010: 147) proposal, which is based on both British and Spanish guidelines (Aenor 2005, Audetel 2000), Vercauteren (2007), Salway (2007) and Turner (2007), was used. Marzà presents a list of elements to be considered when audio describing, which are summarised below:

(1) What to describe: images (where, when, what, who, how), sounds and on-screen texts.

(2) When to describe: during silences, keeping suspense and tension, allowing the original to breathe through the description, synchronising the description with action.

(3) How to describe: clarity in exposition, vocabulary and style, use of present tense, avoiding first-person pronouns, and avoiding personal interpretations.

The present analysis focuses on some relevant aspects of the what and the how since the when was not an issue in the experiment.

Before presenting the results of the analysis, it is worth noting a relevant quantitative difference: whilst the average number of words per description in group 1 (AD training/blind) is 809 words, in group 3 (no AD training/blind) it is 587 words, which shows, according to our hypothesis, a willingness to provide longer and more detailed - descriptions in the case of participants with AD training.

\subsection{What to describe}

Various elements could be considered relevant but we decided to focus on the description of images, and more specifically the setting and the characters because they are key elements. Regarding the setting, the number of references to the selected items (time, place and weather) is indicated in Table 11.

\begin{tabular}{|l|l|l|l|}
\hline Setting & & Group 1 (AD, blind) & Group 3 (no AD, blind) \\
\hline Time- day & (Early) morning & 2 & 2 \\
\hline & Afternoon & 1 & 0 \\
\hline & Midday & 1 & 0 \\
\hline Time-year & Spring/Summer & 2 & 2 \\
\hline & $70 \mathrm{~s} / 80 \mathrm{~s} / 90 \mathrm{~s}$ & 2 & 0 \\
\hline Place & Mountain/rural area & 9 & 8 \\
\hline & Fruit trees valley & 1 & 0 \\
\hline & Mexico & 0 & 1 \\
\hline & Andalusia or South Italy & 0 & 1 \\
\hline Weather & Sunny & 2 & 2 \\
\hline & Warm & 3 & 0 \\
\hline & No clouds & 1 & 0 \\
\hline & & Total: 24 & Total: 16 \\
\hline
\end{tabular}


Table 11. Description of the setting

The results show a tendency in the group of participants trained in AD to use more detail in the description of the setting. References to the fact that the action takes place in a rural area shows up with similar percentages, but it is in the description of the time and weather where differences are found: subjects with AD training tend to indicate the time of the action, although with contradictory descriptions (morning/afternoon/midday), and they also generally describe the weather (sunny, warm, no clouds). It is worth reproducing the detailed description of one informant in group 1, which uses expressions such as "calorosa tarda d'estiu" [hot summer afternoon], "el cel és completament blau i no es veu cap núvol a l'horitzó" [the sky is totally blue and no clouds are to be seen], "les muntanyes rodegen la vall plena de conreus, sobretot d'arbres fruiters" [mountains around a valley full of crops, mainly fruit trees], and "entorn rural i estival" [rural and summer atmosphere].

Identifying and describing characters is considered by most guidelines as crucial but not much specific advice is given, as pointed out by Fresno (forthcoming), who investigates what key features are fundamental in character construction in AD and are better recalled by the audience. Other authors who have made some remarks on the role of characters in AD include McGonigle (2007), Palomo (2008), Mascarenhas (2009) and Orero (forthcoming).

The results of our analysis show that all texts refer to the same characters but descriptions vary in their detail. Subjects with previous AD training usually provide more detail concerning the looks of the characters, mostly centred on their physical description: mainly age and clothes. Table 12 provides a summary of the items described concerning the pear-picker:

\begin{tabular}{|l|l|l|l|}
\hline Description of "pear-picker" & & Group 1 & Group 3 \\
\hline Apron & $\begin{array}{l}\text { (with no further } \\
\text { description) }\end{array}$ & 0 & 1 \\
\hline & White & 2 & 2 \\
\hline & Big pocket & 5 & 1 \\
\hline Neckerchief & $\begin{array}{l}\text { (with no further } \\
\text { description) }\end{array}$ & 1 & 0 \\
\hline Hat & Red & 4 & 3 \\
\hline & $\begin{array}{l}\text { (with no further } \\
\text { description) }\end{array}$ & 0 & 1 \\
\hline Age & Straw & 3 & 1 \\
\hline & Middle-aged & 2 & 0 \\
\hline Clothes & $30-40$ years old & 1 & 0 \\
\hline & Typical of workers & 0 & 1 \\
\hline & Denim & 1 & 0 \\
\hline & Long-sleeved shirt & 1 & 0 \\
\hline Complexion & $\begin{array}{l}\text { Square-patterned } \\
\text { shirt }\end{array}$ & 1 & 0 \\
\hline & Blue shirt & 0 & 1 \\
\hline & Latino/Mexican & 2 & 0 \\
\hline & moustache & 2 & 1 \\
\hline & & Total: 25 & Total: 12 \\
\hline
\end{tabular}

Table 12. Pear-picker's description

Comparing the two groups, subjects with AD training tend to provide more details about the pear-picker, as shown in the previous table: 25 items described in group 1 vs 12 items in group 3. Concerning the type of items described, age is not included in any 
of the texts in group 3 but the rest of selected items ("apron", "neckerchief", "hat", "clothes", "complexion") show up at least once. However, the description of these items is more general in group 3, whilst subjects in group 1 provide more details, generally concerning the colour ("white apron", "red neckerchief", "blue shirt"), the size ("big pocket") and the material ("denim clothes", "straw hat"). It seems therefore that participants trained in $\mathrm{AD}$ are more precise when it comes to providing detail in the description of characters.

In the case of the man with a goat, no indications are included in group 3 except for one text, where it is described as "vestit d'una manera semblant al camperol, tot $\mathrm{i}$ que sense davantal" [wearing similar clothes to those of the peasant, although without an apron]. In group 1 four texts include short descriptions ("home vestit amb una indumentària similar" [man wearing similar clothes], "un altre treballador del camp" [another peasant], "un jove" [a young man] and "camperol" [a farm worker]), which shows a greater awareness about all the characters in the film despite their secondary role.

As for the other characters (the boy on a bike, the girl and the threesome) the results are presented in Table 13.

\begin{tabular}{|l|l|l|l|}
\hline $\begin{array}{l}\text { Description of "boy on a } \\
\text { bike" }\end{array}$ & Group 1 & Group 3 \\
\hline Hat & $\begin{array}{l}\text { (no specific } \\
\text { indications) }\end{array}$ & 1 & 1 \\
\hline & big & 1 & 0 \\
\hline & Straw hat & 2 & 1 \\
\hline & Broad brim & 1 & 0 \\
\hline Neckerchief & Red & 1 & 0 \\
\hline Clothes & Denim & 1 & 0 \\
\hline Age & $9-10-11-12$ & 2 & 3 \\
\hline Description of the girl & Same age & 2 & 2 \\
\hline Age & $\begin{array}{l}\text { (no specific } \\
\text { indications) }\end{array}$ & 2 & 0 \\
\hline Plaits & Long & 1 & 0 \\
\hline & straw & 1 & 0 \\
\hline Hat & $\begin{array}{l}\text { (no additional } \\
\text { indications) }\end{array}$ & 0 & 1 \\
\hline Beautiful & & & \\
\hline Description of the threesome & (no indications) & 1 & 0 \\
\hline Shirts & Colour of the shirts & 1 & 0 \\
\hline & General & 1 & 2 \\
\hline Age & More specific & 3 & 1 \\
\hline & & \\
\hline
\end{tabular}

Table 13. Description of other characters in the film

The degree of detail is again higher in group 1, with specific features which are not found in group 3, such as the colour, size and specific features of the straw hat ("big", "broad brim", "red"), the fact that the girl has long plaits, or the reference to the shirts the threesome are wearing.

Finally, in order to analyse the actions included in the texts, we have used Du Bois' (1980: xii-xiii) description, reproduced in this volume in Chmiel and Mazur's article, to identify 68 actions in the clip, listed in Table 14. Our aim is to analyse how many of these actions are described in both groups to compare the data and see if subjects with $\mathrm{AD}$ training list a greater number of actions. 


\begin{tabular}{|l|l|}
\hline 1 & Man picks pears on a ladder \\
\hline 2 & Man descends the ladder \\
\hline 3 & $\begin{array}{l}\text { Man kneels } \\
\text { Man puts the pears from the pocket of his } \\
\text { apron into one of three baskets }\end{array}$ \\
\hline 4 & He removes a bandana from around his neck \\
\hline 5 & He wipes one of the pears \\
\hline 6 & He returns to the ladder \\
\hline 7 & He climbs back into the tree \\
\hline 8 & A man approaches with a goat on a leash \\
\hline 9 & They pass the basket of pears \\
\hline 10 & The goat strains towards them \\
\hline 11 & The man pulls him past \\
\hline 12 & Picker is at his work \\
\hline 13 & A boy approaches on a bicycle \\
\hline 14 & The boy coasts towards the baskets \\
\hline 15 & The boy stops \\
\hline 16 & The boy gets off his bike \\
\hline 17 & The boy looks up at the picker \\
\hline 18 & The boy puts down his bike \\
\hline 19 & The boy walks toward the baskets \\
\hline 20 & The boy looks again at the picker \\
\hline 21 & The boy picks up a pear \\
\hline 22 & The boy puts it back down \\
\hline 23 & The boy looks once more at the picker \\
\hline 24 & The boy lifts up a basket full of pears \\
\hline 25 & The boy puts the basket down near his bike \\
\hline 26 & The boy picks the bike up and gets on \\
\hline 27 & The boy picks up the basket \\
\hline 28 & $\begin{array}{l}\text { The boy places it on the rack in front of the } \\
\text { handlebars }\end{array}$ \\
\hline 29 & The boy rides off \\
\hline 30 & The man is picking pears \\
\hline 31 & The boy rides down the read \\
\hline 32 & A pear falls from the basket on his bike \\
\hline 33 & $\begin{array}{l}\text { A girl on a bicycle is approaching from the } \\
\text { other direction }\end{array}$ \\
\hline 34 & The boy turns to look at the girl \\
\hline 36 & His hat flies off \\
\hline$T a b 1$ The front wheel of his bike hits a rock \\
\hline 14 List of actions \\
\hline 16
\end{tabular}

\begin{tabular}{|l|l|}
\hline 37 & The bike crashes \\
\hline 38 & The basket falls off \\
\hline 39 & The pears spill onto the ground \\
\hline 40 & $\begin{array}{l}\text { The boy extricates himself from under the } \\
\text { bike }\end{array}$ \\
\hline 41 & The boy brushes off his leg \\
\hline 42 & $\begin{array}{l}\text { Three boys stand there and look at the bike } \\
\text { boy on the ground }\end{array}$ \\
\hline 43 & The three pick up the scattered pears \\
\hline 44 & They put them in the basket \\
\hline 45 & The boy sets his bike upright \\
\hline 46 & Two boys lift the basket of pears back onto it \\
\hline 47 & $\begin{array}{l}\text { The bike boy begins walking his bike in the } \\
\text { direction he was going }\end{array}$ \\
\hline 48 & $\begin{array}{l}\text { The three boys begin walking off in the } \\
\text { other direction }\end{array}$ \\
\hline 49 & $\begin{array}{l}\text { The boy with the table-tennis bat toy sees } \\
\text { the boy's hat on the road and picks it up }\end{array}$ \\
\hline 50 & He turns around \\
\hline 51 & He whistles \\
\hline 52 & The bike boy stops \\
\hline 53 & $\begin{array}{l}\text { The bike boy takes three pears out of the } \\
\text { basket and holds them out }\end{array}$ \\
\hline 54 & The other boy approaches with the hat \\
\hline 55 & They exchange pears and the hat \\
\hline 56 & The bike boy keeps going \\
\hline 57 & $\begin{array}{l}\text { The boy with the paddleball runs back to his } \\
\text { companions }\end{array}$ \\
\hline 58 & He hands a pear to each of them \\
\hline 59 & They continue on eating their pears \\
\hline 60 & The picker descends the ladder \\
\hline 61 & He looks at the two baskets \\
\hline 62 & He points at them \\
\hline 63 & He backs up against the ladder \\
\hline 64 & He shakes his head \\
\hline 65 & He tips up his hat \\
\hline 66 & The three boys approach, eating the pears \\
\hline 68 & The picker watches them pass by \\
\hline
\end{tabular}

Table 14. List of actions

In group 1, i.e. those who have received training in $\mathrm{AD}$, the number of actions included in their narration varies between 23 and 60, with an average of 40 actions per text. On the contrary, the number of actions in the group who has not received training in AD, averages out at 27, ranging from 13 to 35 actions per text. Again, the data show a significant difference between the two groups: whilst subjects with no training in AD narrate the action in a more general way, participants in group 1 tend to separate each of the actions and use more specific verbs.

\subsection{How to describe}

In this sub-section our aim is to assess the use of adjectives in the texts as an element which can show variations in style. The use of adjectives, as stated by Rodríguez (2007: 
159), is vital in order to provide a thorough description and has been one of the aspects highlighted in comparative studies of ADs (Matamala \& Rami 2009: 264, Bourne \& Jiménez Hurtado 2007: 179). Vercauteren (2007: 144) states that "adjectives should be objective, descriptive and specific", and makes some further remarks on the use of adjectives referring to colours, which are relevant even for blind and visually impaired people. The adjectives found in all texts are listed in Table 13 and show a remarkable difference between the 56 adjectives found in group 1 and the 33 adjectives found in group 3.

\begin{tabular}{|c|c|c|}
\hline & Group 1 (AD training) & Group 3 (no AD training) \\
\hline Text 1 & $\begin{array}{l}\text { "gran butxaca" [ big pocket }] \\
\text { "cistells plens" [full baskets }]\end{array}$ & $\begin{array}{l}\text { "paisatge muntanyenc" [ } \text { mountain landscape }] \\
\text { "vegetació groguenca, seca" }[\text { yellowish and } \\
\text { dry vegetation }] \\
\text { "arbres verds" }[\text { green trees }] \\
\text { "camisa blava" [blue shirt }] \\
\text { "mocador vermell al coll" }[\text { red neckerchief }] \\
\text { "peres verdes" }[\text { green pears }] \\
\text { "davantal blanc" }[\text { white apron }]\end{array}$ \\
\hline Text 2 & "mocador vermell" [red neckerchief] & "dia solejat" [sunny day] \\
\hline Text 3 & $\begin{array}{l}\text { "zona rural" [rural area }] \\
\text { "home de mitjana edat" [middle-aged man }] \\
\text { "cistells grossos" [big baskets }]\end{array}$ & $\begin{array}{l}\text { "mocador vermell" [red neckerchief }] \\
\text { "jaqueta blava" [blue jacket }] \\
\text { "davantal blanc" [white apron }] \\
\text { "cabassos grans" [big wicker baskets] }\end{array}$ \\
\hline Text 4 & 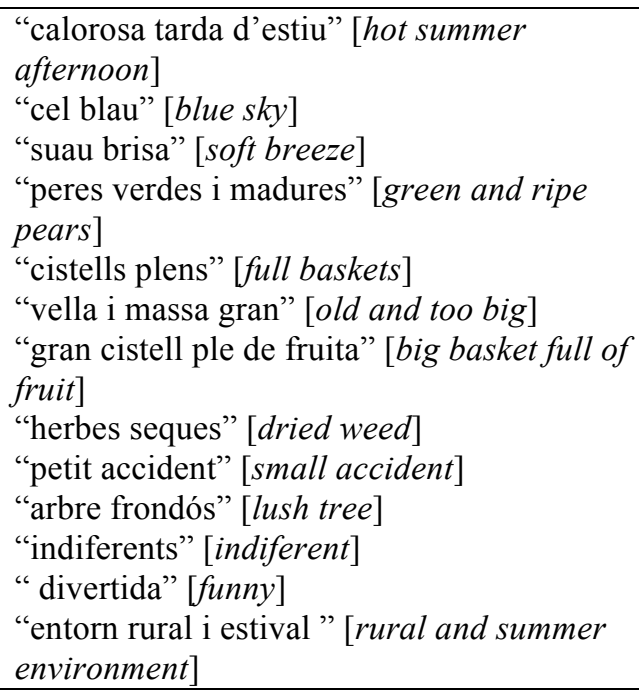 & No adjectivation \\
\hline Text 5 & $\begin{array}{l}\text { "sol imponent" [impressive sun] } \\
\text { "mocador de color vermell sang " } \\
\text { [neckerchief red like blood }] \\
\text { "davantal blanc" [ white apron] } \\
\text { "peres de color verd acid d'àllò més } \\
\text { formoses " [extremely beautiful acid green } \\
\text { pears] (2 occurrences) } \\
\text { "pedra grossa" [ [huge stone }] \\
\text { "camisa blava" [blue shirt }] \\
\text { "camisa groga" [yellow shirt }] \\
\text { "camisa marró" [ brown shirt }] \\
\text { "atònit" [amazed }]\end{array}$ & “cistells plens" [full baskets] \\
\hline Text 6 & $\begin{array}{l}\text { "ambient boscós i força bucòlic" [In a } \\
\text { wooded and quite pastoral atmosphere }] \\
\text { "bicicleta força gran" [quite big bicycle] } \\
\text { "cistells plens" [full baskets] }\end{array}$ & $\begin{array}{l}\text { "sorprès" }[\text { surprised }] \\
\text { "parat" }[\text { shocked }]\end{array}$ \\
\hline
\end{tabular}




\begin{tabular}{|c|c|c|}
\hline & "butxaca plena" [full pocket $]$ & \\
\hline Text 7 & $\begin{array}{l}\text { "entorn rural estiuenc i polsegós" [ rural and } \\
\text { dusty summer environment }] \\
\text { "bigoti fosc" [dark moustache }] \\
\text { "butxaques molt grosses" [very big pockets] } \\
\text { "mocador vermell" [red neckerchief] } \\
\text { "cistells buits" [ } \text { [empty baskets }] \\
\text { "cistells plens" [full baskets }] \\
\text { "so inconfusible" [unmistakable sound }]\end{array}$ & "davantal molt gros" [very big apron] \\
\hline Text 8 & $\begin{array}{l}\text { "cistell ple" [full basket }] \\
\text { "bicicleta grossa" [big bicycle }]\end{array}$ & $\begin{array}{l}\text { "dia molt assoleiat" }[\text { very sunny day }] \\
\text { "escala vertical" }[\text { vertical ladder }] \\
\text { "davantal blanc" }[\text { White apron }] \\
\text { "foulard vermell" }[\text { red neckerchief }] \\
\text { "camp sec" }[\text { dry field }] \\
\text { "bicicleta vermella" }[\text { red bicycle }] \\
\text { "sorra blanca" }[\text { white sand }] \\
\text { "nena força bonica" }[\text { pretty beautiful girl }]\end{array}$ \\
\hline Text 9 & $\begin{array}{l}\text { "home... mexicà" [Mexican-looking man }] \\
\text { "mocador vermell" [ [red neckerchief] } \\
\text { "barret gros" [big hat }] \\
\text { "mocador vermell" [ } \text { red neckerchief }]\end{array}$ & $\begin{array}{l}\text { "dia assolellat, sembla càlid" [ sunny and } \\
\text { apparently warm day }] \\
\text { "gran perera" [big pear tree }] \\
\text { "frondosa" }[\text { lush }] \\
\text { "bastant grossetes" [quite big }] \\
\text { "gran butxaca"[big pocket }] \\
\text { "verdes" [ }[\text { green }]\end{array}$ \\
\hline Text 10 & $\begin{array}{l}\text { "home de mitjana edat" [middle-aged man] } \\
\text { "mocador vermell a l'estil cowboy" } \\
\text { [cowboy-style red neckerchief] } \\
\text { "davantal blanc" [white apron] }\end{array}$ & "cistelles plenes" [ full baskets $]$ \\
\hline
\end{tabular}

Table 15. Adjectives found in the texts

It has been demonstrated that subjects with $\mathrm{AD}$ training use a wider array of adjectives and provide greater detail in their descriptions. Words referring to colours are widely used ("red", "blue", "brown", "yellow"), as well as adjectives related to capacity ("full") and size ("big"). Apart from the use of adjectives, participants with AD training tend to offer longer descriptions with more precise wording, although there are still individual stylistic differences to be found.

\section{Conclusions}

In conclusion, our initial study based on the PSP and included in section 3 has shown no clear-cut differences between the groups and has compelled us to put forward the hypothesis that culture and language play a more significant role than specific target audiences and previous training in the selected items, especially since this training was limited to a 20-hour course and participants were not specifically instructed to write an AD. However, our complementary analysis, based on items not taken into account in the Pear Tree Project (description of setting, characters and actions, and also use of adjectives), has shown remarkable differences in terms of style and detail in the description of the selected groups.

More specifically, this pilot study has shown that students trained in AD tend to provide more specific descriptions of the setting and the main characters in the film. Moreover, they also usually include a greater number of actions, whilst the group of 
translation students without $\mathrm{AD}$ training adopts a more generalising approach. The number of average words of the descriptions in both groups can be considered a clear indicator of the detail given in the descriptions. This leads us not only to state that a limited period of training in $\mathrm{AD}$ already shows in the results - at least in the items selected for the second part of our research - but also to suggest that an intersemiotic translation such as $\mathrm{AD}$ could be an interesting practice both at postgraduate and undergraduate level to improve observation and writing skills, apart from gaining awareness about specific audiences such as the visually impaired.

To sum it up, this article has taken the AD Pear Tree Project a step further and has opened new avenues for research. In our opinion, there are at least two directions that experiments could continue: on the one hand, further experiments based on the Pear Tree Project items of analysis could be devised altering some variables and using a higher number of participants. In other words, it would be interesting to analyse whether modifying the channel of communication (oral/written), the number of viewings (one viewing/no restriction on viewings) or the addressee's profile (blind/sighted) could change the results. It would also be worth researching how specifically instructing participants to create an audio description would change the output. And, finally, it would also be relevant to compare the data from students trained in $\mathrm{AD}$ and from professional audio describers. As indicated, the possibilities of cross referencing variables are manifold but a higher number of participants is needed to go beyond the exploratory studies presented in this article.

On the other hand, a complementary set of items of analysis could be established and the same textual output could be used to carry out further analysis. As previously mentioned, the items chosen were the same as in the original PSP but it might well be that other features are as relevant for $\mathrm{AD}$ analyses - or even more so- as the ones selected to assess the production of narratives in various languages. It is our opinion that these studies should focus on the three items mentioned at the beginning of section 4 : what is described (images, sounds and on-screen texts) and how all these items are described (clarity, vocabulary, style, verbal tenses, personal pronouns and personal interpretation). There is no doubt that further empirical research is needed in the emerging field of $\mathrm{AD}$.

\section{Acknowledgments}

This research is part of the Spanish project FFI2009-0827 and of the Catalan research group Transmedia Catalonia, funded by Generalitat de Catalunya (2009SGR700).

\section{References}

AENOR. (2005). Audiodescripción para personas con discapacidad visual. Requisitos para la audiodescripción y la elaboración de audioguías. UNE 153020 [Audio description for visually-impaired. Requisites for audio description and audio guides]. Madrid: AENOR.

Audetel. (2000). ITC Guidance on Standards for Audio Description. Retrieved from http://www.ofcom.org.uk/static/archive/itc/itc_publications/codes_guidance/audio_desc ription/index.asp.html

Bourne, J. \& Jiménez Hurtado, C. (2007). From the visual to the verbal in two languages: a contrastive analysis of the audio descriptions of The Hours in English and 
Spanish. In J. Diaz-Cintas, P. Orero, \& A. Remael (Eds.), Media for All: Subtitling for the Deaf, Audio Description and Sign Language (pp. 175-187). Amsterdam: Rodopi.

Braun, S. (2008). Audio description research: state of the art and beyond. Translation Studies in The New Millennium, 6, 14-30.

Chafe, W. (Ed.) (1980). The Pear Stories: Cognitive, Cultural and Linguistic Aspects of Narrative Production. Norwood: Ablex.

Du Bois, J.W. (1980). The search for a cultural niche: showing the pear film in a Mayan community. In W. Chafe (Ed.), The Pear Stories: Cognitive, Cultural and Linguistic Aspects of Narrative Production (pp. 1-7). Norwood: Ablex.

Fresno, N. (forthcoming). Experimenting with characters. An empirical approach to the audio description of real characters In M. Carroll, P. Orero \& A. Remael (Eds.), Media for All 3: The Audiovisual Turn. Amsterdam: Rodopi..

Marzà, A. (2010). Evaluation criteria and film narrative. A frame to teaching relevance in audio description. Perspectives. Studies in Translatology 18(3), 143-153.

Mascarenhas, R. (2009). Audio Description and Discursive Strategies: A Study on the Construction of the Characters in "Little Miss Sunshine". Paper presented at the Media for All 3 conference. Antwerp, October 22-24, 2009.

Matamala, A. \& Rami, N. (2009). Análisis comparativo de las audiodescripciones española y alemana de "Good-bye, Lenin" [Comparative analysis of the Spanish and German audio descriptions of "Good-bye, Lenin”]. Hermeneus 11, 249-266.

Mazur, I. \& Chmiel, A. (2011). Towards a common European quality audio description: Final report on the Pear Tree Project. Perspectives. Studies in Translatology, this volume.

McGonigle, F. (2007). The Audio Description of Children's Films. Unpublished M.A. dissertation. Surrey: University of Surrey, UK.

Orero, P. (forthcoming). Audio Description for Children: Once upon a time there was a different audio description for characters. In E. di Giovanni (Ed.) Entre texto y receptor: accesibilidad, doblaje y traducción. Frankfurt: Peter Lang.

Orero, P. (2008). Three different receptions of the same film. 'The Pear Stories Project' applied to audio description. European Journal of English Studies 12(2), 179-193.

Palomo, A. (2008). Audio Description as Language Development and Language Learning for Blind and Visual Impaired Children. Unpublished M.A. dissertation. Castelló: Universitat Jaume I, Spain.

Remael, A. (2005). Audio description for recorded TV. Cinema and DVD. An experimental stylesheet. Retrieved from http://www.artesis.be/vertalertolk/ 
Remael, A. \& Vercauteren, G. (2007). Audio describing the exposition phase of films. Teaching students what to choose. TRANS. Revista de Traductología, II, dossier 11-14, 73-93.

Rodríguez, A. (2007). Consideraciones acerca del lenguaje literario [Considerations on the literary language]. In C. Jiménez Hurtado (Ed.), Traducción y accesibilidad [Translation and Accessibility] (pp. 153-165). Frankfurt: Peter Lang.

RNIB (2010) A Comparative Study of Audio Descriptoin Guidelines Prevalent in Different Countries. RNIB: Media and Culture Department.

Salway, A. (2007). A corpus-based analysis of audio description. In J. Díaz-Cintas, P. Orero, \& A. Remael (Eds.), Media for All: Subtitling for the Deaf, Audio Description and Sign Language (pp. 151-174). Amsterdam: Rodopi.

Seibel, C. \& Jiménez, C. (forthcoming). La traducción accesible a través de la audiodescripción: un estudio contrastivo de la película "Good-bye Lenin" [The accessible translation through audio description: a contrastive study of the film "Goodbye Lenin"]. Actas del II Simposio sobre la traducción e interpretación del/al alemán. Salamanca, March 2007.

Tannen, D. (1980). A comparative analysis of oral narrative strategies: Athenian Greek and American English. In W. Chafe (Ed.), The Pear Stories: Cognitive, Cultural and Linguistic Aspects of Narrative Production (pp. 51-87). Norwood: Ablex.

Turner, J. (1998). Some characteristics of audio description and the corresponding moving image. In C. Preston (Ed.), Proceedings of $61^{\text {st }}$ ASIS Annual Meeting, vol. 35 (pp. 108-117). Medford: Information Today.

Vercauteren, G. (2007). Towards a European guideline for audio description. In J. DíazCintas, P. Orero, \& A. Remael (Eds.), Media for all: Subtitling for the Deaf, Audio Description and Sign Language (pp. 139-150). Amsterdam: Rodopi. 